\title{
LOGAM PADUAN MAGNESIUM SEBAGAI IMPLAN BIODEGRADASI
}

\author{
(MAGNESIUM-BASED ALLOYS AS THE BIODEGRADABLE \\ IMPLANT MATERIALS)
}

\author{
Subhaini Jakfar \\ Departemen Dental Material \\ Faculty of Dentistry, Syiah Kuala University \\ Jl. Tgk. Tanoh Abee, Sektor Selatan, Kopelma Darussalam, Banda Aceh 23111 \\ E-mail: subhaini@yahoo.com
}

\begin{abstract}
Magnesium is potentially used as temporary implant applications caused by its biodegradable properties. This paper discusses about magnesium-based alloys as the biodegradable implant materials. Even as the temporary implant, its characteristic can be manipulated as the permanent implantation that does not need the secondary surgery for implant removal, after the tissues or bones have been recovered. Hence, this material will be degraded and excreted through human metabolism. Even though it has potential in biodegradable and bioresorbable but the fast corrosion rate is being a problem and it can lose implant function, caused by quick degradation, before the tissue is completely healing. In conclusion, improvements in reducing the corrosion rate of magnesium have been done, therefore matching the magnesium's corrosion rate to the bone healing; some of them are mechanical, coating, and processing treatment on composition adjustment, and its toxicity consideration as well.
\end{abstract}

Key words: magnesium, implant, biodegradable, corrosion rate

\begin{abstract}
Abstrak
Magnesium berpotensi digunakan sebagai bahan implan sementara dikarenakan memiliki sifat biodegradasi. Makalah ini membahas tentang logam paduan sebagai implan yang terbiodegradasi. Sifat biodegradasi ini, lebih lanjut dapat dimanfaatkan untuk diaplikasikan sebagai bahan implan permanen yaitu dapat meniadakan pembedahan tahap lanjutan untuk mengeluarkan bahan implan dari bagian tubuh setelah fungsi jaringan tubuh yang digantikannya pulih. Selama berada di dalam tubuh, magnesium mengalami degradasi dan kelarutannya ini dapat diekskresikan ke luar tubuh melalui metabolisme tanpa membahayakan tubuh (biodegradasi). Akan tetapi, meskipun memiliki sifat biodegradasi dan bioresorbable, kecepatan korosi dari logam ini menjadi permasalahan sehingga menurunkan fungsi implan sendiri yaitu mengalami degradasi sebelum jaringan tubuh yang digantikan berfungsi sempurna. Kesimpulannya, penyempurnaan untuk mengurangi kecepatan korosi telah dilaksanakan untuk memperoleh kesesuaian antara kecepatan korosi magnesium dan pengembalian fungsi tulang. Beberapa perlakuan tersebut untuk mendapatkan degradasi yang sesuai dan pembentukan tulang diantaranya melalui perlakuan mekanik, pelapisan, pengaturan komposisi paduan, serta pertimbangan sifat toksisitas dengan jaringan sekitarnya.
\end{abstract}

Kata kunci: magnesium, implan, biodegradasi, kecepatan korosi

\section{INTRODUCTION}

Biomaterials for medical application based on metal alloys have offered more advantages than other materials, such as ceramics, polymers, and composites. Those metal alloys are, for instance, titanium, $\mathrm{CrCr}$ based alloys, stainless steel, magnesium, etc, especially on their mechanical properties. At previous research has been already conducted in order to iden- tify how effective the properties of biomaterial to affect on medical application. Nowadays, biomaterial investigations of based- metal alloys, however, have been carried out successfully not only relating to their biocompatibility but also biodegradable and bioresorbable properties, as existed in magnesium. Magnesium is a very applicably recommended biodegradable property that can be applied properly and 
safely as an implant material because its dissolution is still below about $200-300 \mathrm{mg} /$ day which is normally required for the metabolic human's body activities. ${ }^{1}$ In addition, the magnesium ion is an essential component in human metabolism and is well known to play an important role in the bone formation. And then the continuing research and metal application in medical has been done since it was founded by Sir Humphry Davy in $1808 .^{2}$

The performance of magnesium as implant materials simply contributes to interacting well with the body's tissue which is shown by the osseointegration with bone tissue, and less inflammation reaction by soft tissue even the hydrogen ion production is still formed surrounding implantation as the effect of corrosion. However, no pain reported and almost no infection observed during the postoperative. In relation to this, it is predicted that the forming of hydrogen after implantation has resulted at low level and has already exchanged in vivo., ${ }^{2,3}$ As the process of implantated bone, therefore, it is not only enhancing bone response but also giving the excellent interfacial strength compared to based-alloys titanium by push-out-testing. ${ }^{4}$

Physiology environment also determines the performance of the magnesium-based alloys as implant materials. The biodegradable magnesium can be gradually dissolved, absorbed, consumed or excreted in human body environment, and then disappeared spontaneously after the bone tissue healing. The corrosion of biodegradable materials depends on different physiological parameters like $\mathrm{pH}$ or ion concentration. Corrosion might be varied in different biological environment which correspond to Willbold et al. who reported that the corrosion behavior of the magnesium screw in respect to its original tissue location where the corrosion attacks different site of the screw that the head screw is more progressively attacked than the threaded screw, and then after three months implantation the newly micro callus forming. ${ }^{5}$ Another research reported that the increasing of soaking time of magnesium alloys in simulated body fluid solution will increase the forming of protective film layer on the surface, and then the increasing of soaking time the film layer becomes more compact where after 24 hours the film layer becomes to degenerate and emerge cor-rosion pit and the meantime has deposited hydroxy-apatite on its surface. $^{6}$

In regard with the previous discussion, magnesium biodegradable properties and the effect of human's physiology activities towards the magnesium implant performance in the medical application should be necessarily focused on and treated well for comfort. Put simply, this is a kind of treatment that applied in order to control corrosion rate through mechanic, coating, and processing treatment on composition adjustment, and its toxicity consideration as well.

\section{DISCUSSION}

The unique corrosion rate of magnesium alloys is a reason being metal-based alloys as biodegradable materials. However, the corrosion rate of the implant has to be compatible with the tissue forming at the surrounding implant. Therefore, it is an important thing to regard with the corrosion rate of the biodegradable implant before putting in human's body. The attempts have been done to control corrosion rate of magnesium alloys by performing treatments on the magnesium alloys. ${ }^{7}$

Mechanical treatment can reduce an amount of ion leaching from magnesium surface after implantation in which it is frequently to apply in high temperature but still with temperature below the alloy's melting point. As a consequence of its treatment, some atoms from its constituents in the crystal structure of magnesium alloys get enough energy to rearrange at a new position. Some reports, for instances, said that mechanical treatment of any kind of magnesium alloys can be functioned as a retarder of corrosion in which aluminum content of magnesium-based alloys acts as the protective film on magnesium alloys after hot rolling treatment. ${ }^{8}$ Strontium as binary $\mathrm{Mg}-\mathrm{Sr}$ alloys then can be the hot rolled in controlling hu-ge amount of mechanical strength and reducing much corrosion rate and also suggested that the use of the optimal composition of strontium is about $2 \mathrm{wt} \%$ (weight percent). And based on latest finding in vivo has been succesfully identified to state that it has induced alkaline phosphate activities surrounding implant. ${ }^{9} \mathrm{Li}$ et al. also noticed that for adding strontium of magnesium alloys led to increasing in compressive strength. ${ }^{10}$ Another magnesium based alloys composition like $\mathrm{Mg}-\mathrm{Ca}$ alloys could reduce the fasting corrosion of its alloys through mechanical burnishing to tune surface integrity of $\mathrm{MgCa}$ implant surface for bio-degradation control. ${ }^{1}$

It is considered that composition and processing magnesium based- alloys can also act as controlling of the corrosion rate of its implant materials. ${ }^{11,}{ }^{12}$ For example, mechanical properties of $\mathrm{Mg}-\mathrm{Ca}$ based alloys are very depend on the controlling of $\mathrm{Ca}$ content at processing level which composed of two phases namely; $\alpha(\mathrm{Mg})$ and $\mathrm{Mg}_{2} \mathrm{Ca}$. In line to this, $\mathrm{Mg}-\mathrm{xCa}$ alloys strongly affected their corrosion behavior and degraded in vivo within 90 days and the newly formed bone was clearly seen that displayed at high activity of osteoblast and osteocytes observed around the $\mathrm{Mg}-1 \mathrm{Ca}$ alloys. ${ }^{13}$ By adding stron- 
tium and zinc as the composition of magnesium alloys at a certain amount can increase and reduce the corrosion rate through minimising grain size and enhancing in strength by escalating strontium and zinc content. Furthermore, Binary $0.5 \mathrm{wt} \% \mathrm{Sr}$ was the lowest degradation rate while $0.5 \mathrm{wt} \% \mathrm{Zn}$ increased the corrosion rate with the highest rate at $\mathrm{Mg}$ $0.6 \mathrm{wt} \% \mathrm{Zn}-0.5 \mathrm{wt} \% \mathrm{Sr} .^{14}$ Another reported that by the effect of adding strontium and zirconium onto $\mathrm{Mg}$ $\mathrm{Zr}-\mathrm{Sr}$ alloys processed by diluting $\mathrm{Mg}-\mathrm{Zr}$ and $\mathrm{Mg}-\mathrm{Sr}$ alloys in which zirconium can act as refining grain size, improving ductility, smooth grain boundaries, and enhancing the corrosion resistant of $\mathrm{Mg}$ alloys, whereas, strontium led to increasing in compressive strength and improving better biocompatibility in vitro, and bone formation in vivo. In general, the alloys of $\mathrm{Mg}-\mathrm{Zr}-\mathrm{Sr}$ discussed above is kind of load-bearing implant materials which composed of different composition of zirconium and strontium that will pose different properties of implant. ${ }^{10}$ However, new magnesium alloys ZEK100 consist of zinc, rare earth metals and zirconium showed total degradation and will be affected pathology into host tissue, hence it is not necessarily associated with good biocompatibility. ${ }^{15}$

The coating on the surface of magnesium alloys is another treatment that can be applied to control the corrosion rate of its implant. The coating materials put on implant surface can be taken from similar material or other materials such as polymers, ceramics, and composites. Forming thin layer spread out over the surface of magnesium-based implant aims to control degradation and also allow cell tissues to grow surrounding implant which is not deteriorated by metal ion leaching at initial postoperation. Sulanke et al. reported that degradation rate of magnesium alloys can be reduced by pure magnesium coating. Pure magnesium has lower corrosion rate than alloys while precipitation phase in magnesium alloys can increase corrosion properties of magnesium alloys by different phases. At the first round of 48 hours after implantation process performed the intensity of corrosion keeps maitaning in lower level where at that time the matrix is in progress to form between implant and bone. ${ }^{16}$ Therefore, polymer based coating, nowadays, has largely used to control corrosion rate for some material implant including magnesium-based implant, such as poly (L-lactic acid)

\section{REFERENCES}

1. Salahshoor M, Guo YB. Surface integrity of biodegradable Magnesium-Calcium orthopedic implant by burnishing. J Mech Behav Biomed Mater 2011; 4(8): 1888-904.
(PLLA), and poly ( $\varepsilon$-caprolactone) (PCL). Both PLLA and PCL coating produced by spin coating are to protect and resist from initial corrosion and cytocompatibility. ${ }^{17}$ Another research also reported that coating a controllable polymeric membrane fabricated by polycaprolactone and dichloromethane onto magnesium alloys, as a result, it showed good cytocompatibility of eGFP (enhanced green fluorescent protein) and SaOS-2 (sarcoma osteogenic) osteoblast with higher volume of new bone that observed on polymer-coated implant. ${ }^{18}$

Even though ion leaching of implant based on magnesium alloys reported was still below the amount threshold of human's magnesium ion, but the safety ion consumed by human after implantation should has been taken into consideration by the manufacturers. The protocols of toxicity test of biodegradable are ISO 10993:5 and 10993: 12 have still in debate because these testing standards were originally developed for non-degradable materials, while, some research groups try to avoid these chalenges of in vitro tests by directly performing animal trial after materials development and mechanical characteri-zations of new magnesium implant. Fischer et al. recommended that the using of 10 extract magne-sium for the same standard above which used only onetime extract. ${ }^{19}$ Another consideration is the poor corrosion resistant of implant causes the aqueous' body rich chloride ion that highly corrosive properties on account of increasing hydrogen forming as surrounding of implant materials and tissue damages. ${ }^{20}$

Magnesium-based alloys are potentially used as material for medical implantation taking into account the biodegradable properties contained in it are simply acceptable in body fluid. However, to access good integration into human tissue, the corrosion rates, therefore, have to be controlled, especially at the first round of 48 hours after implantation, to allow tissue to grow surrounding implant. The corrosion rate can be controlled by surface treatment on magnesium implant such as mechanical treatment, coating, and adding other elements into magnesium alloys to enhance the structure of the crystal. Finally, the important thing is to control toxicity and potential ion leaching from its manufacture level before applied to human.

2. Witte F. The history of biodegradable magnesium implants: a review. Acta Biomater. 2010; 6(5): 1680-92. 
3. Kuhlmann J, Bartsch I, Willbold E, Schuchardt S, Holz O, Hort N, et al., Fast escape of hydrogen from gas cavities around corroding magnesium implants. Acta Biomater. 2013. 9(10): 8714-21

4. Castellani C, Lindtner RA, Hausbrandt P, Tschegg $\mathrm{E}$, Stefanie E, Tschegg S, et al. Bone-implant interface strength and osseointegration: Biodegradable magnesium alloy versus standard titanium control. Acta Biomater. 2011; 7(1): 432-40.

5. Willbold E, Kaya AA, Kaya RA, Beckmann F, Witte F. Corrosion of magnesium alloy AZ31 screws is dependent on the implantation site. Materials Science and Engineering: B 2011; 176(20): 1835-40.

6. Song Y, Shan D, Chen R, Zhang F, Han EH. Biodegradable behaviors of AZ31 magnesium alloy in simulated body fluid. Materials Science and Engineering: C 2009; 29(3): 1039-45.

7. Atren A, Liu M, Abidin NIZ. Corrosion mechanism applicable to biodegradable magnesium implants. Materials Science and Engineering: B 2011; 176(20): 1609-36.

8. Wang H, Estrin Y, Zúberová Z. Bio-corrosion of a magnesium alloy with different processing histories. Materials Letters 2008; 62(16): 2476-79.

9. Gu XN, Xie XH, Li N, Zheng YF, Qin F. In vitro and in vivo studies on a Mg-Sr binary alloy system developed as a new kind of biodegradable metal. Acta Biomater. 2012; 8(6): 2360-74.

10. Li Y, Wen C, Mushahary D, Sravanthi R, Harishankar $\mathrm{N}$, Pande $\mathrm{G}$, et al. $\mathrm{Mg}-\mathrm{Zr}-\mathrm{Sr}$ alloys as biodegradable implant materials. Acta Biomater. 2012; 8(8): 3177-88.

11. Witte F, Hort N, Vogt C, Cohen S, Kainer KU, Willumeit R, et al. Degradable biomaterials based on magnesium corrosion. Current Opinion in Solid State and Materials Science 2008; 12(5-6): 63-72.

12. Guo YB, Salahshoor M. Process mechanics and surface integrity by high-speed dry milling of biodegradable magnesium-calcium implant alloys. CIRP Annals-Manufacturing Technology 2010; 59(1): $151-4$.
13. Li Z, Gu X, Lou S, Zheng S. The development of binary $\mathrm{Mg}-\mathrm{Ca}$ alloys for use as biodegradable materials within bone. Biomaterials 2008; 29(10): 1329-44.

14. Brar HS, Wong J, Manuel MV. Investigation of the mechanical and degradation properties of $\mathrm{Mg}-\mathrm{Sr}$ and $\mathrm{Mg}-\mathrm{Zn}-\mathrm{Sr}$ alloys for use as potential biodegradable implant materials. J Mech Behav Biomed Mater 2012; 7: 87-95.

15. Dziuba D, Andrea ML, Seitz JM, Waizy H, Angrisani $\mathrm{N}$, Reifenrath J. Long-term in vivo degradation behaviour and biocompatibility of the magnesium alloy ZEK100 for use as a biodegradable bone implant. Acta Biomater. 2013; 9(10): 8548-60.

16. Salunke P, Shanov V, Witte F. High purity biodegradable magnesium coating for implant application. Materials Science and Engineering: B 2011; 176(20): 1711-17.

17. Xu L, Yamamoto A. Characteristics and cytocompatibility of biodegradable polymer film on magnesium by spin coating. Colloids Surf B Biointerfaces 2012; 93: 67-74.

18. Wong HM, Yeung KWK, Lam KO, Tam V, Chu PK, Luk KDK, et al. A biodegradable polymer-based coating to control the performance of magnesium alloy orthopaedic implants. Biomaterials 2010; 31(8): 2084-96.

19. Fischer J, Pröfrock D, Hort N, Wellumeit R, Feyerabend F. Reprint of: Improved cytotoxicity testing of magnesium materials. Materials Science and Engineering: B 2011; 176(20): 1773-77.

20. Ulrich A, Ott N, Fillon AT, Homazava N, Schmutz $\mathrm{P}$. Investigation of corrosion behavior of biodegradable magnesium alloys using an online-microflow capillary flow injection inductively coupled plasma mass spectrometry setup with electrochemical control. Spectrochimica Acta Part B: Atomic Spectroscopy 2011; 66(7): 536-45. 